\title{
Assessment Of Farmers' Perception Towards Soil And Water Conservation Measures At Bako Tibe District, Western Ethiopia
}

Getu Emiru Gonde ( $\sim$ getuemiru89@gmail.com )

Oda Bultum University

Getahun Kitila

Wollega University

\section{Research Article}

Keywords: Adopted soil water conservation, Farmers' perception, Soil and water conservation, Soil erosion

Posted Date: March 8th, 2022

DOI: https://doi.org/10.21203/rs.3.rs-1394926/v1

License: (c) (i) This work is licensed under a Creative Commons Attribution 4.0 International License.

Read Full License 


\section{Abstract}

In Ethiopia, Soil erosion is one of the very chronic environmental problems. It needs attention to carried out conservation measures to tackle the problem and conservation of the environmental resource is the most crucial activities. However, the study on the farmer's perception towards soil and water conservation measures has not been well investigated in the Bako Tibe district, western Ethiopia. Therefore, this study was undertaken to assess farmer's perception towards soil and water conservation measures in the study area. The major source of data was a formal household survey. The data was collected by field observation, administer questionnaire, semi structured interview and focus group discussions. The household survey data have been collected and analyzed by utilizing the statistical package for social science (SPSS) version 20.0 Software. The study revealed that farmers of the study area perceived soil erosion as a problem constraining crop production and have knowledge of soil and water conservation measures. The majority of farmers in the study area have the willingness in adoption and conservation of the Soil and Water Conservation. This shows the sustainability of the soil and water conservation in the study area. And also, the farmers stated that they benefited in reducing soil erosion, increase soil fertility, increase crop production and also forage for livestock. The most of farmers of the study area were interested in adoption and conservation of the soil and water conservation structures and majority of them understood the benefits of the conservation in soil erosion control and improve the soil fertility.

\section{Introduction}

\subsection{Background}

Soil is the most important environmental resources which support all fauna and flora of the world. The whole creation depends on the soil which is the ultimate foundation of life existence (Kibemo, 2011 as cited in Mebrahten, 2014). Coexistent in time, the depletion of natural resources is among major problems facing humans throughout the world. Nine million hectares of the world lands are enormously degraded and the original function severely degraded. However, 1.2 billion hectares of the world land was moderately degraded. Worldwide inappropriate agricultural practices account for $28 \%$ of the degraded soils (Addisu, 2011). However, most economies in sub-Saharan Africa (SSA) are agriculture based and about two-thirds of Africans depend on agriculture for their livelihoods. Most farmers are smallholders with an average farm size of between 0.5 to $2 \mathrm{ha}$. It encourages the users to deteriorate the quality of soil (FAO, 2004). The results of exploiting land use systems without consideration of the consequences on soil quality have been environmental degradation (Imeson et al., 2006).

Soil and water conservation in Ethiopia was not merely closely related to the improvement and conservation of ecological environment, but also to the sustainable development of its agricultural sectors and its economy at large level. In Ethiopia, efforts towards soil and water conservation goal were started since the mid-1970s and 1980s (USAID, 2000; Wogayehu and Darke, 2002). Soil and water conservation measures mostly implemented on cultivated lands with a few exceptions are physical structures mainly stone or soil bunds. The efforts to promote soil and water conservation technologies so 
far seem below the threshold which has limited the sustained use of natural resources for a better production and conservation (Mulugeta and Karl, 2010; as cited in Haweni, 2015). Knowing farmers' perception of soil erosion and its impact is important in promoting soil and water conservation technologies. Awdenegest and Holden (2006) reported that studies conducted in different areas have shown that farmers have knowledge of soil conservation measures. Study made by (Aseffa, 2009) states that farmers perceived soil erosion as a problem constraining crop production. The most important top soil for crop production activity was deteriorating over time due to erosion processes.

Hence, they observed on cultivated lands top soil reduction and the number of stones in their land has been increasing over time (Wagayehu and Lars, 2003). The problem of soil erosion and the conservation of the implemented structures and fewer participants during the work of the soil and water conservation structures and less consideration for implemented structures regarding its conservation, lack of enough farm land encourage farmers to deteriorate their land quality. The research gaps were not well studied before on the interest and perceptions of farmers on soil and water conservation measures in the study area. Therefore, the objective of this paper was to assess the farmers' perception towards SWC measures and to identify the SWC structures adopted in the study area.

\section{Material And Methods}

\subsection{Geographical Environment of the Study Area}

The study was conducted at Bako Tibe district of west Shewa zone of Oromia national regional state, western Ethiopia. The district is located at about 250 and $125 \mathrm{~km}$ from Addis Ababa and Ambo respectively along the main road to the west direction of Ethiopia. It is bounded by the Jima Rare and Jima Geneti in the North, Cellia and Ilu Galan District in the East and Gobu Sayo and Gudeya Bila district in the West and Boneya Boshe district in South. Geographically, the study area lies between $9^{\circ} 00$ to $9^{\circ}$ $10 \mathrm{~N}$ latitude and $37^{\circ} 00$ to $37^{\circ} 9 \mathrm{E}$ longitudes and at an altitude of 1650 meter above sea level (masl) (Fig. 1). The total area of the district is about $644.94 \mathrm{~km}^{2}$ (Abera, 2014; BTAO, 2019).

The topography of the study area is slightly undulating especially in the highlands and almost flat in the lowlands. The study area has $22 \%$ steep, $60 \%$ flat, $4.5 \%$ gorge, $5 \%$ hill and $5.2 \%$ others (BTAO, 2019). The long-term weather data (1990 to 2017) revealed that the area has a unimodal rainfall pattern, and mean annual rainfall was observed as $1273 \mathrm{~mm}$ and average relative humidity is $67.2 \%$. The rainy season covers from April to October, and maximum rain was received in the months of June, July and August (Abera, 2014). About $80 \%$ of the mean annual rainfall is received from June to September. It has a warm humid climate with the mean minimum, mean maximum and average air temperatures of 13.4, 28.49 and $20.95^{\circ} \mathrm{C}$ respectively (BTAO, 2019). The study area covers three agro-ecological zones: low land (Gammoojjii) 51\%, midland (Badda Daree) 12\%, and high land (Baddaa) 37\% based on temperature, rainfall, altitude and vegetation covers. The high-altitude zone occupies the largest area followed by mid and low altitude climatic zones respectively. The study area has relatively favorable agricultural potential, which is reflected in the diversity of crops and animal resources. The area has different land use/cover 
$54.25 \%$ of land is arable or cultivable, $23.98 \%$ is for pastures, and $5.12 \%$ of land is covered by forest and $16.65 \%$ of the land is for built upland (BTAO, 2019). The major soil types of the study area are red soil (Biyyoo Diimaa) 55\%, Black cotton Soil/Vertisols (Biyyoo Kooticha) 5\%, Black soil (Biyyoo Gurraacha) 15\% and Brown soil (Biyyoo Magaala) 25\% (BTAO, 2019). The dominant soil in the area is reddish brown in color Nitosols. The textural class of soil of the study area is dominantly clay and loam in texture (BARC, 2014). The study area is endowed with diverse vegetation species ranging from little dense and old natural forests in pocket areas at tips of both up and down stream sides, to the patch of sparse shrubgrass complex in various areas. Dominant tree species in the area include Cordia Africana (Waddeessa), Ficusvaita (Qilxuu) and Croton mycrostachyus (Bakkaniisa), Acacia abysinica (Laaftoo), Vernonia amygadalina (Eebicha), Ocimum sauva (Hancabbii), Grewia ferruginea (Dhooqonuu), Calpurnia aurea (Ceeka), Olea Africana (Ejersa), and the exotic tree species Eucalyptus camalduleses (Bargamoo diimaa) are the main vegetation species of the study area. Eucalyptus camalduleses (Bargamoo diimaa) is widely found in the study area. The drainage pattern of the study area is stretched from North to South directions. The study area has the major rivers such as Gibe (laga Gibe), Sama (laga saama), Jima (laga Jimaa), Qela (laga Qallaa), Mara (laga Maraa), Leku (laga Lakkuu), and Habuko (laga Habukkoo). Precipitation is the main source for recharge of these rivers flow in the study area (Bako Tibe Agricultural Office, 2015). The district has 28 rural and 4 urban peasant association/kebeles. The total population size of the district is 65,293 men and 68,291 women totally 133,584 with a total house hold size of 22,880 (Bako Tibe Agricultural Office, 2019). The area is characterized by mixed farming system where the major livestock raised are Cattle, Sheep, Goat, Equines, and Poultry. The major annual and perennial crops of the area includes Maize ( Zea mays L.), Sorghum (Sorghum bicolor), Teff (Eragrostis tef), Wheat (Tiriticum vulgare), Barley (Hordeum vulgare), Nigger seed (Guizotia abyssinica), Beans (Vicia faba) and Peas (Pisum sativum), Hot pepper (Capsicum frutescense L.), Haricot bean (Phaseolus vulgar L.), Sweat potato ( Ipomoea batatas Lam), Mango ( Mangifera indica L.), Banana (Mussa spp), and Sugar cane (Saccharum officinarum L.) in order of importance. Other diverse forms of livelihoods observed in the study area includes small-scale irrigation from rivers, springs and drainage for temperate and subtemperate fruit and cash crop production (vegetables such as Onion (Allium cepa), Garlic (Allium sativum), Potato (Solanum tuberosum), Cabbage (Brassica oleracea), Tomato and different types of spices. Maize and Pepper are the dominant crops grown in the area (BTAO, 2019).

\subsection{Methods}

\subsubsection{Sampling Size and Techniques}

Bako Tibe district has 32 kebeles, of which 28 of them were peasant associations (PAs) and 4 urbans administrative kebeles. The district has total population 65,293 men and 68,291 women totally 133,584 with a total house hold size 22,880. In order to get the representative kebeles and households two stage sampling techniques were employed. The first stage was used to select the sample study kebeles, from the large number of Bako Tibe district association kebeles, while the second stage was used to select sample households for questionnaire. In the first stage, the kebeles selected purposively based on conservation measures and erosion sensitive area which leads to the soil quality deterioration, two 
sample peasant associations/kebeles namely Dambi Dima and Dambi Gobu were selected. In the second stage, the sample households (farmers) from two kebeles, which include 1099 households, were selected purposively from the kebeles' village and then simple random sampling method was conducted by means of lottery method. Because of large number of households, it is difficult to administer questionnaires and conduct interviews to all of the household heads of the sampled Kebele households. Thus, the researcher was select 92 households (10\%) from total households' heads. Development Agents (Das), government authorities and other concerned bodies were also included as key informants. To determine the sample size of the households the researcher was used the below formula stated by Yamane (1967).

$\mathrm{n}=\mathrm{N} / 1+\mathrm{N}(e)^{2}=1099 / 1+1099(10 \%)^{2}$

$1099 / 11.99$

$91.65 \approx 92$ households were selected

Where $\mathrm{n}$ is sample size, $\mathrm{N}$ is Population size (total household heads), $\mathrm{e}$ is the level of precision (10\%).

\subsubsection{Type and Source of data}

Both relevant qualitative and quantitative data were collected from primary and secondary sources. The primary data for qualitative study was collected from elders, community leaders and farmers who have adequate knowledge and information about the past and present environmental conditions of the study area. The primary data was collected from sampled household farmers. Secondary data for quantitative study such as description about the study area, location, topography, climate, population, land management practices were collected from published and unpublished documents of different Governmental Organizations and the district agriculture office.

\subsubsection{Data collection techniques}

Field observation was one method of data collection method employed to generate relevant information about the area and ensure the validity of information collected by another method. It contributed the areal information on the field visit in detail to extend the impacts and practices which already grounded in the area. Close and open-ended format question was prepared and distributed to the selected sample household heads to get information about farmers' perception to SWC practices and the general condition of the study area. The questionnaire was primarily prepared in English language version and translated in to "Afan oromo" language and it was distributed to the respondents. Semi-structured interview was conducted, because of its flexibility and makes clear when there is confusion in the questionnaire for further information.

Regarding focus group discussion, respondents were selected based on socially respected or the elder within the society to investigate the environmental condition and who are having better knowledge on the present and past environmental, social and economic status of the study area. 


\subsubsection{Statistical data analysis}

The collected data from household questionnaire survey was entered and analyzed using SPSS (statistical package for social sciences) version 20.0 software and the results were presented with descriptive statistics; tables and percentages. The qualitative data was generated by the focus group discussions were used to verify the results from the questionnaires.

\section{Results And Discussions}

\subsection{Demographic Characteristics of the Respondents}

The demographic characteristics of the respondent include sex, age, marital status, education level, occupational status, family size and land holding size. These are the major paramount respondent's description incorporated under this chapter. In addition to this it tried to manifests the major cause of soil resources degradation, the farmer's perception to soil erosion and the responsive measures to hamper the soil erosion problem and soil water conservation measures undertaken. 
Table 3.1

demographic characteristics of respondents

\begin{tabular}{|c|c|c|}
\hline Sex & Frequency & Percent (\%) \\
\hline Male & 79 & 85.9 \\
\hline Female & 13 & 14.1 \\
\hline Total & 92 & 100.0 \\
\hline \multicolumn{3}{|c|}{ Age category } \\
\hline $20-30$ & 7 & 7.6 \\
\hline $30-40$ & 34 & 37.0 \\
\hline $40-50$ & 26 & 28.3 \\
\hline$>50$ & 25 & 27.2 \\
\hline Total & 92 & 100.0 \\
\hline \multicolumn{3}{|c|}{ Marital status } \\
\hline Single & 2 & 2.2 \\
\hline Married & 77 & 83.7 \\
\hline Divorced & 2 & 2.2 \\
\hline Widowed & 11 & 12.0 \\
\hline Total & 92 & 100.0 \\
\hline \multicolumn{3}{|l|}{ Family size } \\
\hline 0 & 3 & 3.3 \\
\hline $1-5$ & 44 & 47.8 \\
\hline $5-10$ & 33 & 35.9 \\
\hline above10 & 12 & 13.0 \\
\hline Total & 92 & 100.0 \\
\hline \multicolumn{3}{|c|}{ Education status } \\
\hline Illiterate & 41 & 44.6 \\
\hline grade $1-4$ & 18 & 19.6 \\
\hline grade 5-8 & 23 & 25.0 \\
\hline grade $9-12$ & 10 & 10.9 \\
\hline
\end{tabular}




\begin{tabular}{|cll|}
\hline Sex & Frequency & Percent (\%) \\
\hline Total & 92 & 100.0 \\
\hline Occupational status & & \\
\hline on farm & 86 & 93.5 \\
\hline off farm & 4 & 4.3 \\
\hline other work & 2 & 2.2 \\
\hline Total & 92 & 100.0 \\
\hline (Survey, 2020) & & \\
\hline
\end{tabular}

$85.9 \%$ of respondents were male headed households and the other $14.1 \%$ female headed households (Table 3.1). In the study area the male households were participated in the conservation practices by their forces mainly and the female heads were mostly responsible in the home as food worker. Similarly, study made by Melese (2016) explained that male household heads participated more actively than female household heads in SWC practice because female household heads have more responsibilities at home. Sex of the household heads were also determining access to soil and water conservation technological information provided by development agents and soil and water conservation projects implementing in the study area.

The respondents beyond the age of $>50,37.2 \%$ were stated that age also influence the soil water conservation work and they did not take part as a labor for the digging the bund and other structures but they have interest and age limit their activity. According to Tsegaye (2014) age of a household head plays an important role in household decision on use of different technologies including SWC practices. According to marital status of respondents showed some of widowed farmers were not participated in soil water conservation due to their children age and follow up education. According to interview conducted some of illiterate respondents were had the idea of the erosion hazardous and stated that if the soil and water conservation program is not adopted the soil and the other resources were caused great damages. Above grade $9-12$ respondents $10.9 \%$ were respond that at program level, soil and water conservation is a precious and more preferable practice for livelihood of the community but to change this program in to practice was still under problem in this district (Table 3.1).

Similarly, Habtamu (2014) explained that better educated households have more perceptions that are realistic about soil erosion problem, have more knowledge on SWC, and can easily involve in conservation activities. In the same line Haweni (2015) stated that education level of farmers is assumed to increase the ability to obtain and use of agricultural related information and technology in a better way.

\subsection{Farm characteristics of respondents}

Farm characteristics of the respondents were included farm land size, grazing land, and the livestock population. $5.4 \%$ of respondents viewed that the land holding ownership and small land holding size 
determine the farmers' interest to adopt these technologies and also conservation practices (Table 3.2). Those groups were rented land from others and cultivated on that farm land without considering the health of that soil. This leads to deteriorate the quality of the soil. This idea familiar with Habtamu (2014) showed that, more soil and water conservation practices adoption were practiced on larger plots. The majority of the farmers $46.7 \%$ of the study area have the farm land $1-2 \mathrm{ha}$. This study agrees with Melese (2016) who reported that farmers with small land holdings think that constructing the physical structures decrease their plots so that they hesitate to adopt the technologies. In the study area the land scarcity was observable problem and farmers faced by the problem of soil erosion and lack of fallowing the land in order to resilient the shock. 
Table 3.2

Farm characteristics of respondents

\begin{tabular}{|c|c|c|}
\hline Farm land size & Frequency & Percent \\
\hline No & 5 & $5.4 \%$ \\
\hline 0.5 ha & 21 & $22.8 \%$ \\
\hline 1-2ha & 43 & $46.7 \%$ \\
\hline 2-3ha & 17 & $18.5 \%$ \\
\hline 3-4ha & 4 & $4.3 \%$ \\
\hline$>4 \mathrm{ha}$ & 2 & $2.2 \%$ \\
\hline Total & 92 & $100.0 \%$ \\
\hline Grazing land size & Frequency & Percent \\
\hline No & 31 & $33.7 \%$ \\
\hline 0.25 & 27 & $29.3 \%$ \\
\hline $0.25-0.5$ & 24 & $26.1 \%$ \\
\hline 0.5-1ha & 10 & $10.9 \%$ \\
\hline Total & 92 & $100.0 \%$ \\
\hline Cattle size & Frequency & Percent \\
\hline 0 & 16 & $17.39 \%$ \\
\hline $1-5$ & 31 & $33.70 \%$ \\
\hline $5-10$ & 28 & $30.43 \%$ \\
\hline$>10$ & 17 & $18.5 \%$ \\
\hline Total & 92 & $100 \%$ \\
\hline Sheep and goat & Frequency & Percent \\
\hline 0 & 24 & $26.08 \%$ \\
\hline $1-4$ & 36 & $39.13 \%$ \\
\hline $4-8$ & 18 & $19.56 \%$ \\
\hline $8-12$ & 11 & $11.95 \%$ \\
\hline$>12$ & 3 & $3.26 \%$ \\
\hline Total & 92 & $100 \%$ \\
\hline Equines & Frequency & Percent \\
\hline
\end{tabular}


(Survey, 2020)

\begin{tabular}{|cll|}
\hline Farm land size & Frequency & Percent \\
\hline 0 & 26 & $28.26 \%$ \\
\hline 1 & 38 & $41.30 \%$ \\
\hline 2 & 28 & $30.43 \%$ \\
Total & 92 & $100 \%$ \\
\hline
\end{tabular}

Livestock population of the study area was mentioned from the dominant to the rare animal Cattles (bull, oxen, cows and culf), sheep, and equines. Most of the farmer's has 1-5 Cattles 33.70\%, 1-4 sheep and goat 39.13 and 1 equines $41.30 \%$ respectively (Table 3.2). Farmers of the study area were kept livestock for different purposes. The animals are kept to provide food, draft and transport, as a means of assets to be saved them when problem caused and used as capital and income generation. Especially in the study area oxen were kept for plowing and fattening of the livestock is not practiced as it needed.

\subsection{Major causes of soil resource degradation in the study area}

Most of respondents reported that over cultivation and grazing is the most and serious problem of the study area in deterioration of soil resources which accounts $44.6 \%$ and rugged topography, human population density, lack of conservation structures, and very small landholding size which accounts 30.4 , $12,7.6$, and $5.4 \%$ respectively influences the natural resources in addition to the soil in study area (Table 3.3). Farmers with small land holding size cultivate the land continuously and adding nitrogen fertilizer but this could be cause soil acidity and decrease the crop production. The population density increment causes the land scarcity which result soil degradation rather than treating this resource. This study argued that the "More People-Less Erosion (MPLE)" hypothesis, studies made in Kenya, Machakos village indicates the more population the more environmental conservation and labor availability (Tiffen et al., 1994). Because of the density of population, farmers of the study area were cultivated on the marginal lands and most susceptible land to erosion and even plow river banks for the cultivation purpose by clearing the forest patches around the river. As a result, Population increases have limited the use of fallowing, and continuous cultivation has become an inevitable practice in the study area.

The issue of sustainable development and its pillars couldn't achieve the requirements of pure economic development, political stability and social needs is due to the failure of environmental resources. 
Table 3.3

causes of soil degradation in the study area

\begin{tabular}{|lll|}
\hline Causes of Soil degradation & Frequency & Percent (\%) \\
\hline rugged topography & 28 & 30.4 \\
\hline over cultivation and grazing & 41 & 44.6 \\
\hline human population density & 11 & 12.0 \\
\hline lack of conservation structures & 7 & 7.6 \\
\hline very small land holding size & 5 & 5.4 \\
\hline Total & 92 & 100.0 \\
\hline (Survey, 2020) & & \\
\hline
\end{tabular}

\subsection{Farmers' opinion on the soil fertility declines and measures undertaken}

According to the questionnaire and interview conducted all of the farmers understood the decline of their farm land nutrient. Also they dictate that different indicators that showed the nutrient decline on their farmland. $100 \%$ of respondents said that without adding the fertilizer which is increased from the past year and for the next without adding the input in larger amount it did not bears expected yield. Not only the yield diminished but also stunted growth of plant, inferior grain quality, and color change on leaves were the other soil nutrient decline on the farm land.

This study familiar with Aklilu and Jan de Graaff (2004) most of farmers reported a decline in soil fertility in their farm plots over the years. The reasons given included continuous cultivation, soil erosion, insufficient use of artificial fertilizers, and moisture stress. Population increases have limited the use of fallowing, and continuous cultivation has become an inevitable practice in the study area. Because of this, farmers practices physical soil and water conservation to tackle the soil erosion problem. Similarly, in study made by Mebrahten (2014) farmers have been awareness of the problem of soil erosion and soil fertility decline and believed that the severity of the problem had increased over time. Farmers knew the problems were more severe in the untreated land units than the SWC treated. According to respondents said the most indicator of soil nutrient decline in the study area were production decline, stunted growth of plant, inferior grain quality, and color change on leaves which accounts 59.8, 25.0, 9.8, and 5.4\% respectively. Farmers stated that the most indicator of the soil nutrient decline in the study area was production decline as generated from interview and questionnaire disseminated showed.

The soil fertility of the farm land improved by using different measures among these the farmers of the study area were mainly used artificial fertilizer to increase the production and a little people use manure and some were used fallowing but this fallowing method is not more practiced by most of farmers 
because of land shortage and the land holding size. It also covers 96.7, 2.2 and 1.1\% inorganic fertilizer, fallowing and farm yard manure application respectively

\subsection{Farmer's perception in past soil water conservation practices}

The district natural resource experts stated that at the beginning of the project conflicts arose usually on bund spacing, farmers being not happy with construction and closely spaced soil bunds mainly due to labor shortage and more use of land. However, the problem is resolved later through training and awareness creation

Farmers of the study area were stated their views in the past the soil and water conservation work was started in the form of incentive to adopt and later government disseminate the issue of conservation at Kebele level to practice farmers on their land. Some of them were argued that the structures were taken the land and trouble to plough the land by oxen. According to Abera (2003) conservation measures were in most cases physical measures and undertaken through campaign using Food-for-Work (FfW) or Cashfor-Work (CfW) as an instrument to motivate farmers to putting up the conservation structures both on communal holdings as well as on their own plots.

The majority of farmers of the study area was participated in soil and water conservation programs formerly and also has positive perception on the conservation work as the questionnaire and interview conducted indicated. $96.7 \%$ of respondents were participated and $3.3 \%$ of respondents were not participated this reason is stated in table (3.15). Farmers of the study area understand the soil and water conservation benefits for their environment and mainly on erosion reduction. And also study made by Assefa (2009) states that farmers perceived soil erosion as a problem constraining crop production. Similarly, the study made by Awdenegest and Holden (2006) state that farmers have knowledge of soil conservation measures.

\subsection{Community participation in soil water conservation practices}

The community of the study area participated in different forms sending food for worker during the conservation practices, direct involvement as a labor by force and supporting by giving material for this work. Among these respondents most of the farmers were participated by their force which accounts 73.9\%. The others 14.2 and $12.0 \%$ were showed community participated in sending food and giving material respectively. Community of the study area was participated in the conservation in different forms to enrich the environmental requirement in which human being survive in freely. This is the perception of farmers at what status the community participation being on and the general manifestation of community on the conservation concerning their views as very good, good, moderate, and very low and the activity well going on very good by community which expressed as $46.7 \%$ and $26.2,25.0$ and 2.2 were good, moderate and very low respectively in participation. 
Feeling is the actual psychological influences which hinder the working brain to abstain its duty functionally. In this conservation farmers of the study area were categorized under three groups highly satisfied, satisfied and dissatisfied. The interview result showed that most of farmers of the study area were satisfied to the work of soil conservation which accounts about $58.7 \%$ and surprisingly $38 \%$ of respondents responded highly satisfied to the conservation and seen as their major work in addition to their formal work. Some of respondents stated their views for the conservation as no cause and effect covered 3.3\%.

\subsection{Organizations support the community on soil water conservation in the district}

In its nature, the work of soil and water conservation require the integration of multidisciplinary fields in which one sector merely not enrich the required and necessary objective. The government made the relation in the different sector to work together in the district. This shows the integrated relationship in the sector and most paramount in the continuity of the conservation work in the district. The major district organs take part in this conservation work as the community assist were district agricultural office, district administration office and district water and irrigation office.

Table 3.4

Organizations support the community on soil water conservation in the district

\begin{tabular}{|lll|}
\hline Name of organizations & Frequency & Percent (\%) \\
\hline District Agricultural Office & 80 & 87.0 \\
\hline District Administration Office & 4 & 4.4 \\
\hline District Water and Irrigation Office & 8 & 8.7 \\
\hline Total & 92 & 100.0 \\
\hline (Survey, 2020) & & \\
\hline
\end{tabular}

As showed in the above table (3.4) district agricultural office actually assist the community $87 \%$ and others 8.7 and $4.4 \%$ were District Water and Irrigation Office and District Administration Office respectively.

\subsection{Farmers interest in future conservation and its sustainability}

Most of the farmers had the idea that today's activity influences the next generation without conserving the today's resource under exploitation wisely. These indicated as the interest of the farmers for future conservation and ensure sustainability of the work. Almost $96.7 \%$ of respondents had future interest for 
this work and care in a manner of no other choice for the next generation without handling today's resource wisely. And 3.3\% respondents had no interest as questionnaire interpretation. This is line with the study made by Fikru (2009) farmers have interest to conserve their soil and water but they were demand more appropriate technologies and if not properly designed it causes erosion even in areas treated with Soil and Water Conservation structures. Soil and water conservation is the issue of intra generation and inter generation needs that can be ceased suddenly. All of the life parts of the earth's planet depend on the soil and water that enable the parts to survive.

\subsection{Benefits of soil and water conservation practices}

The ultimate benefit of soil and water conservation practice is to reduce the surface runoff and soil water erosion that causes the onsite and offsite impacts. Both impacts cause the sedimentation and siltation, damage the infrastructure, and deteriorate the water quality and yield decrease, soil loss, and causes plant root exposure and river bank soil loss. As the soil erosion decreased the soil fertility and crop production. Actually, conservation structures improve the problem of forage to feed livestock. Soil water conservation has different benefits in the study area $47.8,25.0,18.5$ and $8.7 \%$ were reduce soil erosion, increase soil fertility, increase crop production and forage for livestock respectively. The improved crop yield was possibly due to the effect of soil conservation techniques on soil fertility which was also reported as the advantage of SWC techniques in the study area. This finding familiar with the work of worku et al. (2012) stated that SWC increase soil fertility and consequently improved crop yield.

\subsection{Soil and water conservation structures adopters}

The table below showed that $34.8 \%$ of farmers were adopted the structures on the farm land and most of the farmers $65.2 \%$ of the study area did not adopt the soil and water conservation structures on the land. And the respondents were stated the reasons not adoption were such as flat farm land, small farm size, land ownership and the work are not arrived us.

Table 3.5

soil and water conservation structure adopters

\begin{tabular}{|llll|}
\hline Is there SWC structures done on your farm plot? & Frequency & Percent (\%) \\
\hline Yes & 32 & 34.8 \\
\hline No & 60 & 65.2 \\
\cline { 2 - 4 } & Total & 92 & 100.0 \\
\hline (Survey, 2020) & & \\
\hline
\end{tabular}

\subsection{Farmers' knowledge before SWC program introduced to study area}


Farmers of the study area has indeginous knowledge such as using channel ditches (Bo'oo baasuu), planting tree (Muka dhaabuu), contour farming (Dalga qotuu) and water ways (Yaa'a Bishaanii/daangaa qotuu) to safe the land from the soil erosion hazardous. According to UN (1992) as cited in FAO (1993) Indigenous knowledge is the result of social learning. It is generated through a social interaction as a person tries to make environment suitable for living. Mostly the farmers of the study area were practiced channel ditches (bo'oo baasuu) as questionnaire and field observation showed and $77.2 \%$ covered by this practice. Others such as planting tree (Muka dhaabuu), contour farming (Dalga qotuu) and water ways (Yaa'a Bishaanii) were covers 3.3, 9.8 and $9.8 \%$ respectively.

Table 3.6

Farmers' knowledge before SWC program introduced to safe soil from erosion

\begin{tabular}{|lll|}
\hline Formerly practices & Frequency & Percent \\
\hline Channel ditches (bo'oo baasuu) & 71 & 77.2 \\
\hline Planting tree & 3 & 3.3 \\
\hline Contour farming & 9 & 9.8 \\
\hline Water ways & 9 & 9.8 \\
\hline Total & 92 & 100.0 \\
\hline (Survey, 2020) & & \\
\hline
\end{tabular}

\subsection{The adopted soil and water conservation structures in the study area}

The construction of soil and water conservation structures used to respond the expectations of controlling desertification by reducing the degradation of drainage basins, and even rehabilitating them. It slows the erosion process, retain water, promote better vegetation cover, increase the protection of drainage basins and therefore reduce the damage caused by erosion. Similarly, Addisu (2011) stated that Soil and water conservation practices are tools that farmers use to prevent soil degradation and building organic matter. In addition to this soil and water conservation practices should aim to preventing or at least minimizing the soil loss. Similarly, again WFP (2005) stated that Soil bund is effective in controlling soil loss, retaining moisture, and ultimately enhancing productivity of land. 
Table 3.7

The adopted soil and water conservation structures in the study area

\begin{tabular}{|lll|}
\hline Structures & Frequency & Percent \\
\hline soil bund & 45 & 48.9 \\
\hline stone bund & 34 & 37.0 \\
\hline water ways & 6 & 6.5 \\
\hline cut-off drains & 7 & 7.6 \\
\hline Total & 92 & 100.0 \\
\hline (Survey, 2020) & & \\
\hline
\end{tabular}

In the study area soil bund is mostly practiced and next to the soil bund the stone bund and as the respondents said the stone bund is depend on the presence of the stone if not the others such as cut of drains and water ways practiced by individual farmers mostly. The newly introduced SWC measures, stone and soil bunds, were widely acknowledged as being effective measures in arresting soil erosion and as having the potential to improve land productivity in the study area.

\subsection{Challenges in Soil and Water Conservation activities in the study area}

Table 3.8

Challenges in soil water conservation activities in the study area

\begin{tabular}{|lll|}
\hline Challenges & Frequency & Percent (\%) \\
\hline low income & 8 & 8.7 \\
\hline low level of education & 11 & 12.0 \\
\hline low level of health & 8 & 8.7 \\
\hline low level of information & 29 & 31.5 \\
\hline age level & 14 & 15.2 \\
\hline availability of transport & 1 & 1.1 \\
\hline distance from the project & 6 & 6.5 \\
\hline lack of awareness & 15 & 16.3 \\
\hline Total & 92 & 100.0 \\
\hline (Survey, 2020) & & \\
\hline
\end{tabular}

The most challenges to practice the soil water conservation in the study area were low level of information $31.5 \%$ and next to this lack of awareness $16.3 \%$ also the problem. The scattered and far 
away fields are one of the factors that discourage farmers from adopting SWC measures. In the study area farmers were faced different constraints to adopt soil water conservation such as unable to adopt new technologies, land tenure insecurity and ownership, lack of initiative, lack of interest and lack of awareness's. Mostly in the study area lack of initiation of the community was also hinder the practices from adoption and conservation structures enormously. According to Habtamu (2014) Lack of information, scientific knowledge, and extension services are barriers to adopting conservation practices. Experts discouraged from adopting new technologies or practices by time-honored practices because of low awareness's of farmers on soil and water conservation.

\section{Conclusion}

This study concluded that majority of farmers of the study area has interest and perceived soil erosion as problem and the soil conservation program as their main work and accepted positively. This study showed that, the adopted soil and water conservation structures were limited to small area of the district and the conservation work was not reached most of the farmers of the study area. This study tried to assess the farmers' perception and initiate them in adoption, conservation and identify the adopted structures and challenges and constraints while the conservation. Soil and Water Conservation structures were improved the soil quality and ensure sustainable agricultural productivity. Most of the conservation structures have been adopted on cultivated fields and all of them are physical measures and crop rotation rarely practiced among biological methods.

\section{Declarations}

\section{Acknowledgement}

First of all, I thank the Almighty God for giving me the strength and go through with my studies. I would particularly like to extend my heartfelt thanks and deep gratitude to my advisor Dr. Getahun Kitila for his follow-up, devotion of his precious time, valuable suggestions, constructive comments, ideas and intellectual guidance to improve the content of this paper from beginning to the end. I would like to thanks Bako Tibe District Agriculture Office, Bako Agriculture Research Center, and Expert of Natural Resource Management for their valuable support and Shelema Bate, Mr. Tadesse and Bayisa for their time devotion during data collection and other technical assistance. I would like to extend my appreciation for all interviewed and focused group discussion farmers for their giving me time and permission to observe their plots and also for soil sampling those stood beside me. I am most deeply grateful to my parents, especially my father Emiru Gonde and my mother Mulunesh Merga for pushing me in the world of education and adding me the line of educated men. And also, my thanks go to Wondimu Gonde and all my relatives helping me strive towards the realization of my potentials, initiation, encouragement, and moral support for the accomplishment of my study. 
Finally, I would like to appreciate the Ministry of Education (MoE) for giving the chance and particularly Wollega University for giving the program.

\section{Funding}

The study entitled "Assessment of Farmers' Perception towards Soil and Water Conservation Measures at Bako Tibe district, Western Ethiopia" funded by ministry of education of Ethiopia. The author recruited under ministry of education and the ministry support to conduct this research and the funding source dully acknowledged.

\section{Availability of data and material}

Data undertaken under this study was from available material and all sources were cited and referenced.

\section{Author information}

\section{Affiliations}

Department of Natural Resource Management, College of Natural Resource and Environmental Science, Oda Bultum University, Chiro, Ethiopia.

Getu Emiru

Department of Soil Science, Wollega University, Nekemte, Ethiopia

Getahun Kitila

\section{Contributions}

The first author prepared the first draft and all the manuscript. The other author read, review and approved the manuscript.

\section{Ethics declarations}

Ethics approval and consent to participate

The authors declare that they have no known competing financial interests to influence the work.

\section{Consent for publication}

The authors agree on the publication of the manuscript without any argument.

\section{Competing interests}

The authors declare there is no competing interest. 


\section{References}

1. Abera Degefa. (2014). Effects of Different Soil Management Practices under Maize-Legume Production System on Soil, Water, Nutrient and Yield in Bako, West Oromia, Ethiopia. Pp. 45.

2. Addisu Damtew. (2011). Benefits and challenges of adopting soil conservation techniques in Goromti Watershed, Central Ethiopia. MSc thesis. Addis Ababa University, Ethiopia.

3. Aklilu Amsalu and Jan de Graaff. (2004). Farmers' views of soil erosion problems and their conservation knowledge at Beressa watershed, central highlands of Ethiopia. Journal of agriculture and Human Values.P.10.

4. Assefa Derebe. Assessment of Upland Erosion Processes and Farmer's Perception of Land Conservation in Debre-mewi Watershed, near Lake Tana, Ethiopia. New York: Cornell University; 2009.

5. Awdenegest Moges and S. Holden. Farmers' Perceptions of Soil Erosion and Soil Fertility Loss in Southern Ethiopia. Land Degrad Dev. 2006;18:543-54.

6. BARC. (2014). Bako Agricultural Research Center.

7. BTAO. (2015). BakoTibe Agricultural Office annual report.

8. FAO. National Resource Degradation. In: the state of Food and Agriculture. Italy: Rome; 1993.

9. FAO. (2004). Methodological framework for land degradation assessment in dry-lands.

10. Fikru Assefa. (2009). Assessment of Adoption Behavior of Soil and Water Conservation Practices in the Koga Watershed, highlands of Ethiopia. A Thesis Presented to the Faculty of the Graduate School of Cornell University. P75.

11. Habtamu Olana. Challenges of soil and water conservation practices and measure to be undertaken, the case of wuchale district, north Shewa zone. Ethiopia: Oromia regional state; 2014.

12. Haweni Habtamu(. Effect of Soil and Water Conservation on Selected Soil Characteristics in Dimma Watershed, Central Ethiopia. Ethiopia: Addis Ababa University; 2015. p..p 30-1.

13. Imeson A, Arnoldussen A, De la Rosa D, Montanarella L, Dorren L, Curfs M, Arnalds O, Van Asselen S. Scape:Soil conservation and protection in Europe. The way ahead. Luxembourg: CEE-JRC; 2006.

14. Kibemo Detamo(. Farmers' perception on soil erosion and their use of structural soil conservation measures in Soro district southern Ethiopia. Ethiopia: Addis Ababa university; 2011.

15. Mebrahten Teklechal(. Farmers' Perception of Soil Erosion and Adoption of Soil Conservation Measures in KollaTembienTabiaAwotbkalsi. Ethiopia: Tigray Regional State; 2014.

16. Melese Mache. (2016). adoption of soil and water conservation practices among smallholder farmers: the case of Boloso Sore woreda, Wolaita zone, SNNPR, Ethiopia.

17. Mulugeta D, Karl S. Assessment of integrated soil and water conservation measures on key soil properties in South Gonder. North-Western Highlands of Ethiopia; 2010.

18. Tiffen M, Mortimore M, Gichuki F. More people, less erosion: Environmental recovery in Kenya. New York: John Wiley and Sons; 1994. 
19. Tsegaye Feyissa. Adoption of Soil and Water Conservation Measures in Kundudo Mountain Catchment, Jarso District, East Hararghe Zone, Oromia National Regional State. Haramaya University; 2014.

20. USAID. (2000). Amhara NationalRegional state food security research assessment report.

21. Wagayehu Bekele and Lars Drake. Soil and Water Conservation Decision Behaviour of Subsistence Farmers in the eastern highlands of Ethiopia. A case study of the Hunde-Lafto; 2003.

22. WFP (World Food Program). Report on the Cost-Benefit analysis and Impact Evaluation of Soil Conservation and Forestry Measurement. Ethiopia: MERET. Addis Ababa. Ethiopia. Regional state; 2005.

23. Bewket W and Drake.L. (2002). Adoption of soil and water conservation measures by Subsistence farmers in the Eastern Ethiopia. Presented at the 17th world congress of soil science, Bangkok, Thailand.

24. Yamane T. Statistics: An Introductory Analysis. 2nd ed. New York: Harper and Row; 1967.

\section{Figures}




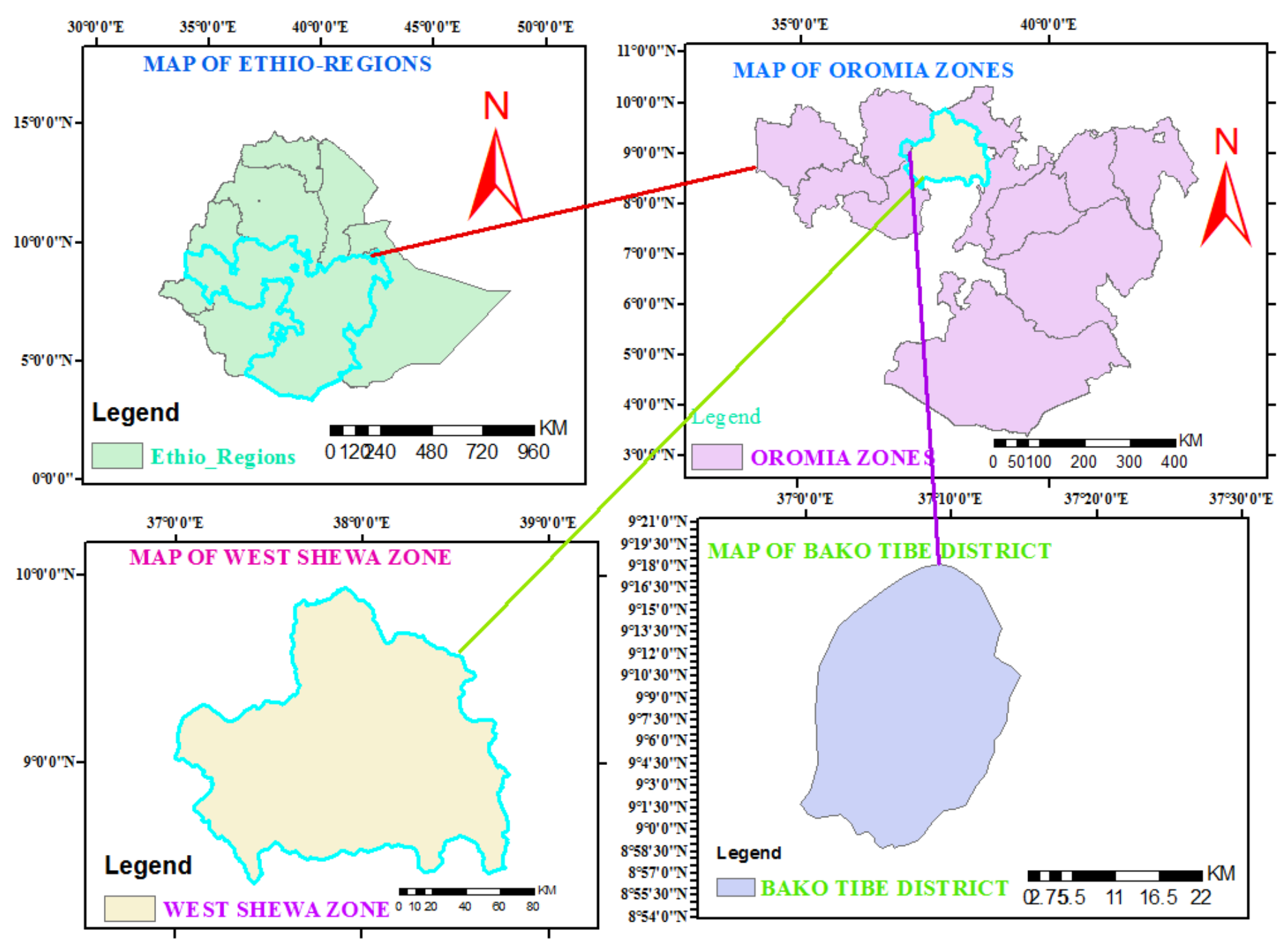

Figure 1

Location map of the study area 